\title{
Efficiency of Bioconversion of Coffee Pulp using Hermetia illucens (Diptera: Stratiomyidae) Larvae
}

\author{
Karen Ospina-Granobles and Nancy Carrejo-Gironza* \\ Departamento de Biología, Facultad de Ciencias Naturales y Exactas, Universidad del Valle, \\ Santiago de Cali, Colombia
}

\begin{abstract}
In this study, we evaluate the capacity of Hermetia illucens (L.) to degrade coffee pulp, which is a highly contaminating residue and a by-product of processing coffee beans. The larvae were fed with dietary dosages of 60, 100, 160, and $200 \mathrm{mg} / \mathrm{larva} /$ day of Coffea arabica (L.) Castillo variety $(0.5 \%$ caffeine $)$, until they reached pupae stage. With a dietary supply of $100 \mathrm{mg} /$ larva/day, the highest reduction percentage $(\% \mathrm{R})$ on a wet basis $(62.88 \%)$ and efficiency of conversion of ingested food (ECI) (7.89\%) were achieved, while with a dietary supply of $160 \mathrm{mg} / \mathrm{larva} /$ day the highest weight reduction index (WRI) in a wet basis was achieved (0.85\%). Larvae fed $200 \mathrm{mg} /$ larva/day had the highest weight (115.9 $\mathrm{mg}$ ) and shortest average development time (38.65 days). In this study we were able to define which dietary supplies of 160 and $200 \mathrm{mg} /$ larva/day, allowing for efficient bioconversion of coffee pulp.
\end{abstract}

Keywords: Bioconversion, coffee pulp, Hermetia illucens

\section{INTRODUCTION}

In coffee-growing countries such as Colombia, the most abundant residue during the processing of coffee beans is the

\footnotetext{
ARTICLE INFO

Article history:

Received: 17 August 2020

Accepted: 23 November 2020

Published: 24 February 2021

DOI: https://doi.org/10.47836/pjtas.44.1.14

$\overline{\text { E-mail addresses: }}$

karen.ospina@correounivalle.edu.co (Karen Ospina-Granobles)

nancy.carrejo@correounivalle.edu.co (Nancy Carrejo-Gironza)

* Corresponding author
}

pulp, which is one of the main contaminants when it is dumped into the environment (Blandón et al., 1999; Pandey et al., 2011). This situation has impelled the coffeeproducing countries to seek for alternatives for the management and use of the coffee pulp (CP), aiming with this to mitigate its impact. Among the alternatives that are handled are the use of coffee pulp as a raw material for the production of animal feed, beverages, vinegar, biogas, caffeine, peptic enzymes, protein, and fertilizer, among others (Noriega et al., 2008; Rodríguez \& 
Zambrano, 2010). The use of coffee pulp as part of the diet of cattle, sheep, pigs, poultry, fish, rabbits, among others, has been limited by the presence of partially negative compounds, such as tannins and caffeine (Noriega et al., 2008; Rubio, 1973), the latter being considered the most nutritionally negative compound (Molina et al., 1990) given than its average concentrations, in coffee varieties such as Arabica, varies between 0.5 to $1.3 \%$ (Elías, 1978).

A potential alternative, which can efficiently minimize the impact caused by CP dumping, is bioconversion with Hermetia illucens (L.) larvae, a Diptera from the Stratiomyidae family, commonly known as "black soldier fly", whose larvae are characterized by being voracious consumers of organic matter of plant or animal origin (Diener, 2009), manure (Banks et al., 2014; Gamboa \& Jasbón, 2008; Newton et al., 2005b) and corpses (Lord et al., 1994; PujolLuz et al. , 2008). Due to the presence of strong mouthparts and digestive enzymes, the larvae can consume large amounts of waste much faster and more efficiently than any other fly larvae (Kim et al., 2011). These characteristics make the black soldier fly a potential organism in the management of organic solid waste such as CP.

An implementation of the use of $H$. illucens larvae in CP management will have a great impact in developing countries such as Colombia, since in comparison with other biodegradation processes, such as composting and worm farming, it will not only reduce up to $56 \%$ of the initial volume of fresh waste (Newton et al., 2005a), but will as well generate by-products such as larval biomass, which can be used as biodiesel when its fat is extracted (Zheng et al., 2011, 2012), as larvae flour for feeding animals such as birds, pigs, fish, and amphibians (Arango et al., 2004; Bondari \& Sheppard, 1987; Hale, 1973; Newton et al., 2005b) and for the extraction of chitin, for use in the medical industry. All these by-products would support local economies, representing an additional source of revenue (Warburton \& Hallman, 2002).

Worldwide, there are many studies on the efficiency of bioconversion of $H$. illucens larvae on cattle, pig, and poultry manure. In Colombia, bioconversion studies with $H$. illucens larvae have focused on the production of larvae flour for animal feed (Canary, 2009), reduction of urban solid waste (Jaramillo \& Zapata, 2008) and reduction of vegetables (Parra et al., 2015). Here we seek to evaluate the efficiency of $H$. illucens in bioconversion of $\mathrm{CP}$, based on parameters such as percentage reduction $(\% \mathrm{R})$, reduction index (WRI) (Diener et al., 2009), and efficiency of conversion of ingested food (ECI) (Oonincx et al., 2015a). Additionally, the effect of feeding with CP on the development of these immatures is evaluated.

\section{MATERIAL AND METHODS}

The trials were carried out under greenhouse and laboratory conditions at the Universidad del Valle Meléndez, Colombia location $\left(3^{\circ} 22^{\prime} 37.18\right.$ “N., 76³1'48.60“W). The specimens used in the tests were obtained from the H. illucens colony at the Universidad del Valle. 
Fresh pulp of Coffea arabica (L.) Castillo variety $(0.5 \%$ of caffeine) was used, sourced from coffee farms located in the village of El Faro, Corregimiento Los Andes, in Valle del Cauca Colombia $\left(3^{\circ} 25^{\prime} 26.3\right.$ ' $\left.\mathrm{N} \mathrm{76} 35^{\circ} 34.6^{\prime \prime} \mathrm{W}\right)$. In order to avoid biological contamination and aerobic fermentation, the pulp was transported in dark plastic containers.

For comparison purposes, organic fruitbased residues (papaya, melon, banana, and pineapple) were used. To ensure the homogeneity of all waste, they were reduced to sizes similar to $\mathrm{CP}(1.5-2 \mathrm{~cm})$.

In order to determine the base physical composition (fixed), taking into account that all residues were used fresh, their moisture was determined and moisture percentages were defined on a wet basis. The moisture percentage was determined by taking fresh $5 \mathrm{~g}$ samples and drying them in an oven at $105^{\circ} \mathrm{C}$ for $24 \mathrm{~h}$ (Diener et al., 2009), the remaining moisture was measured on an Ohaus analytical balance [Equation (1)].

$$
\begin{aligned}
& \% H=\left(\frac{(W 1-W 2)}{W 1}\right) * 100 \\
& \% \mathrm{H}=\text { Moisture percentage }(\%) \\
& \mathrm{W}_{1}=\text { Initial wet weight in grams } \\
& \mathrm{W}_{2}=\text { Final dry weight in grams }
\end{aligned}
$$

\section{Bioconversion Speed}

Based on the works of Diener et al. (2009, 2011) and Myers et al. (2008), four treatments were performed with four repetitions each. Each treatment contained 200 larvae, selected following the suggestions by Sheppard et al. (2002). Each treatment contained 60, 100, 160, and $200 \mathrm{mg} / \mathrm{larva} /$ day (fresh weight with $80 \%$ humidity), corresponding to $12,20,32$, and $40 \mathrm{mg} /$ larva/day dry weight, identified as $\mathrm{T} 1, \mathrm{~T} 2, \mathrm{~T} 3$, and $\mathrm{T} 4$, respectively.

Six-day-old larvae were deposited in "larval incubators" or acrylic containers built to scale, following the specifications proposed by Parra et al. (2015), and covered with a plastic film to prevent moisture loss and contamination by other arthropods (Banks et al., 2014). Each "larval incubator" had a capacity of 1.2 larvae $/ \mathrm{cm}^{2}$.

Every three days, the food from the different treatments was replaced. For this purpose, all the surviving larvae were moved to another container with the initial standardized conditions, and the residues or remaining "larvacomposite" (excrement and undigested material contents), were weighed with the help of an analytical balance, both fresh and dry, the latter being obtained after drying the residues at $105^{\circ} \mathrm{C}$ for 24 hours, thus determining the dry weight.

All trials were carried out until 50\% of the larvae reached the prepupa stage, a prepupa being identified when its coloration changes from light to dark (Diener et al., 2009).

\section{Bioconversion Time, Survival Rate and Larval Weight Gain}

Every six days, from each treatment, 20 larvae were selected at random and their weight was recorded. Once weighed, the specimens were returned to the corresponding "larval incubator". 
Likewise, as they developed, each prepupa was weighed until the end of the trials.

To determine the larval survival rate, the number of live larvae at the end of the trials was divided with respect to the initial number of larvae per treatment (Oonincx et al., 2015a).

\section{Bioconversion Efficiency}

The bioconversion efficiency was determined by the reduction percentage $(\% \mathrm{R})$ on a dry basis [Equation (2)] (Diener et al., 2009).

$$
\% R=\left(\frac{T-R}{T}\right) * 100
$$

$\mathrm{T}=$ material added to the system

$\mathrm{R}=$ Non-ingested feed + Excrement

The waste reduction rate (WRI) [Equation (3)] is obtained from the reduction percentage [Equation (3)] and the number of days $(\mathrm{t})$ that the reduction process takes. According to Diener et al. (2009), a high reduction rate relates to high reduction efficiency.

$W R I=\left(\% \frac{R}{t}\right)$

$\mathrm{R}=$ reduction percentage

$\mathrm{t}=$ bioconversion rate, defines as the time

taken by $50 \%$ of larvae to become prepupa

The efficiency of conversion of ingested food (ECI) measures the larval capacity to utilize the ingested feed in growth (Waldbauer, 1968). It is calculated by taking into account the ingested feed in relation to the weight gained [Equation (4)].

$E C I=\left(\frac{L w f-L w i}{I}\right) * 100$

I = Ingested feed (Supplied Feed - Noningested Feed + Excrement)

$\mathrm{L}_{\mathrm{wi}}=$ Initial larval weight

$\mathrm{L}_{\mathrm{wf}}=$ Final larval weight

The relative growth rate ( $R G R$ ) (Scriber \& Slansky, 1981), considers the relationship between the efficiency of conversion of ingested food and the relative feed consumption. It takes into account the food consumed, the excreted, as well as the assimilated [Equation (5)] (Manurung et al., 2016).

$$
\begin{aligned}
& R G R=\frac{L w f-L w i}{T * L w i} \\
& \mathrm{~L}_{\mathrm{wf}}=\text { Final larval weight } \\
& \mathrm{L}_{\mathrm{wi}}=\text { Initial larval weight } \\
& \mathrm{T}=\text { Time }
\end{aligned}
$$

\section{Statistical Analysis}

With a randomized experimental design, analysis of variance (ANOVA) was used for comparisons between treatments, while an LSD test allowed defining the best treatment. All analyses were performed in the $\mathrm{R}$ program version 3.0.0.

\section{Effect of Caffeine on the Development of Hermetia illucens}

To evaluate the effect of caffeine on the duration of immature stages, four trials were performed, all using $667 \mathrm{~cm}^{2}$ "larval 
incubators", designed to scale according to the specifications of Parra et al. (2015), covered with a plastic film to prevent moisture loss and contamination by other arthropods (Banks et al., 2014).

Five hundred (500) newly emerged $H$. illucens larvae were deposited in "larval incubators" and fed $40 \mathrm{mg} /$ larva/day (dry weight), two diets were used: 1) solid vegetal waste (SVW) and 2) coffee pulp (CP), each diet with four repetitions. All larvae were fed until 50\% had molted into prepupa, however, observations were continued until all larvae either molted into prepupa or died (Tomberlin et al., 2002). Daily, grown prepupae were transferred to containers containing moist soil and covered with organza as a medium for pupa formation. The duration of the pupa was recorded (Figure 1).

\section{RESULTS}

\section{Bioconversion Efficiency}

A dietary supply of 100, 160, and $200 \mathrm{mg} /$ larva/day (80\% humidity), produced an average reduction (dry weight) of $32,30.22$, and $30.96 \%$ respectively (Table 1 ). No significant differences were found among all four treatments. However, a dietary supply of $100 \mathrm{mg} /$ larva/day, presented the highest average percentage of reduction (32\%). Regarding the average percentage of reduction on a wet basis, significant differences were found between these and the treatments, $\mathrm{T}_{2}(100 \mathrm{mg} / \mathrm{larva} /$ day $)$ reaching an average percentage of reduction of $62.88 \%$. The average percentage of reduction on a dry basis ranged from 30.22 to $32 \%$.

In Table 1, it can be seen that, for the average percentage reduction in dry and wet weight, it has an inverse linear relationship (Figure 2).

The index of reduction (WRI) in the analyses with wet basis (WW) and dry basis (DW), can be appreciated in the Table 1, where significant differences were found in both trials. For the wet weight the higher index of reduction $(0.85)$ was observed in the $\mathrm{T}_{3}$ treatment (160 mg/larva/day), while,

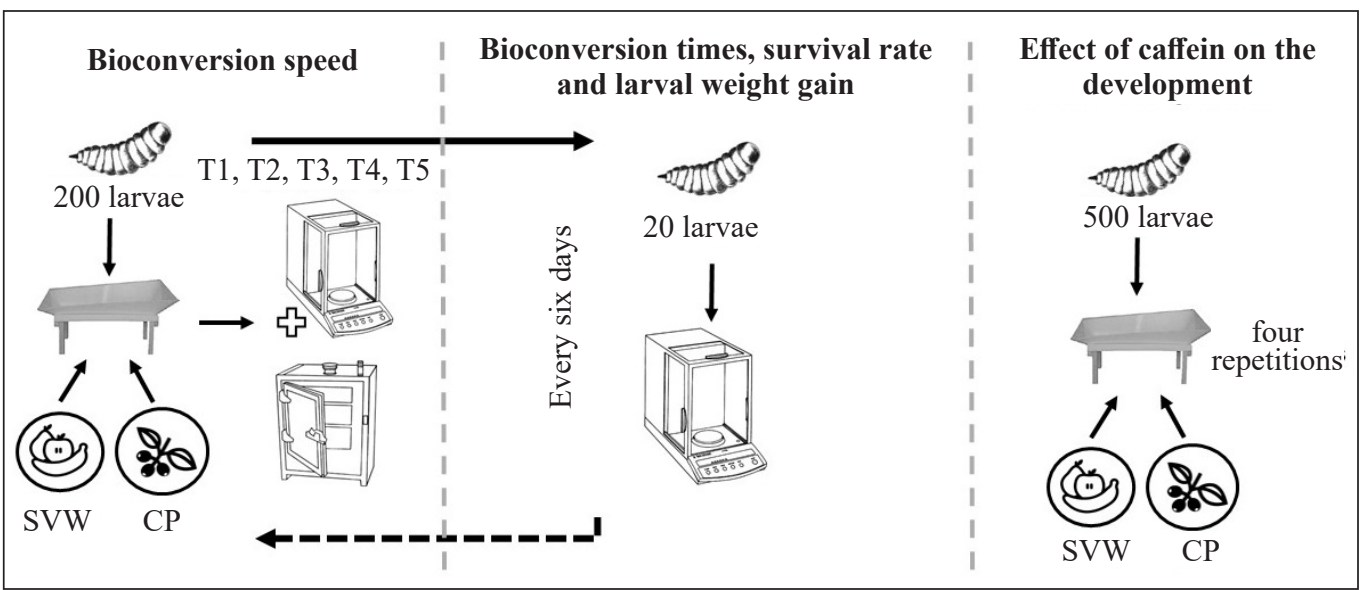

Figure 1. Methodology flow diagram 
Table 1

Parameters of bioconversion efficiency of Hermetia illucens larvae fed with CP

\begin{tabular}{lcccccc}
\hline \multirow{2}{*}{\multicolumn{1}{c}{ Parameters }} & \multicolumn{2}{c}{$\mathrm{T}_{2}$} & \multicolumn{2}{c}{$\mathrm{T}_{3}$} & \multicolumn{2}{c}{$\mathrm{T}_{4}$} \\
& 100mg/larva/day & 160mg/larva/day & \multicolumn{2}{c}{ 200mg/larva/day } \\
\cline { 2 - 7 } & Average & SE & Average & SE & Average & SE \\
\hline Bioconversion time (days) & $77.95 \mathrm{a}$ & 1.08 & $46.45 \mathrm{~b}$ & 0.47 & $\mathbf{3 8 . 6 5 c}$ & 0.32 \\
Survival rate (\%) & $76.00 \mathrm{a}$ & 4.17 & $80.90 \mathrm{a}$ & 4.11 & $89.11 \mathrm{a}$ & 4.11 \\
\%R (reduction percentage) WW* & $\mathbf{6 1 . 8 8 a}$ & 0.66 & $51.25 \mathrm{~b}$ & 3.15 & $29.79 \mathrm{c}$ & 2.03 \\
\%R (reduction percentage) DW* & $32.00 \mathrm{a}$ & 0.47 & $30.22 \mathrm{a}$ & 0.68 & $30.96 \mathrm{a}$ & 0.5 \\
WRI (reduction index) WW & $0.61 \mathrm{~b}$ & 0.01 & $\mathbf{0 . 8 5 a}$ & 0.03 & $0.63 \mathrm{~b}$ & 0.04 \\
WRI (reduction index) DW & $0.31 \mathrm{a}$ & 0.005 & $0.50 \mathrm{~b}$ & 0.01 & $\mathbf{0 . 6 6 c}$ & 0.02 \\
ECI (Efficiency of Conversion of Ingested Food) & $3.9 \mathrm{~b}$ & 0.11 & $\mathbf{7 . 8 9 a}$ & 0.29 & $\mathbf{6 . 1 8 a}$ & 0.24 \\
DW expressed in \% & & & & & &
\end{tabular}

Note. $\mathrm{DW}^{*}$ : dry weight; WRI: weight reduction index; $\mathrm{WW}^{*}$ : wet weight. Average values followed by an identical letter means that they do not vary significantly $(p<0.05)$

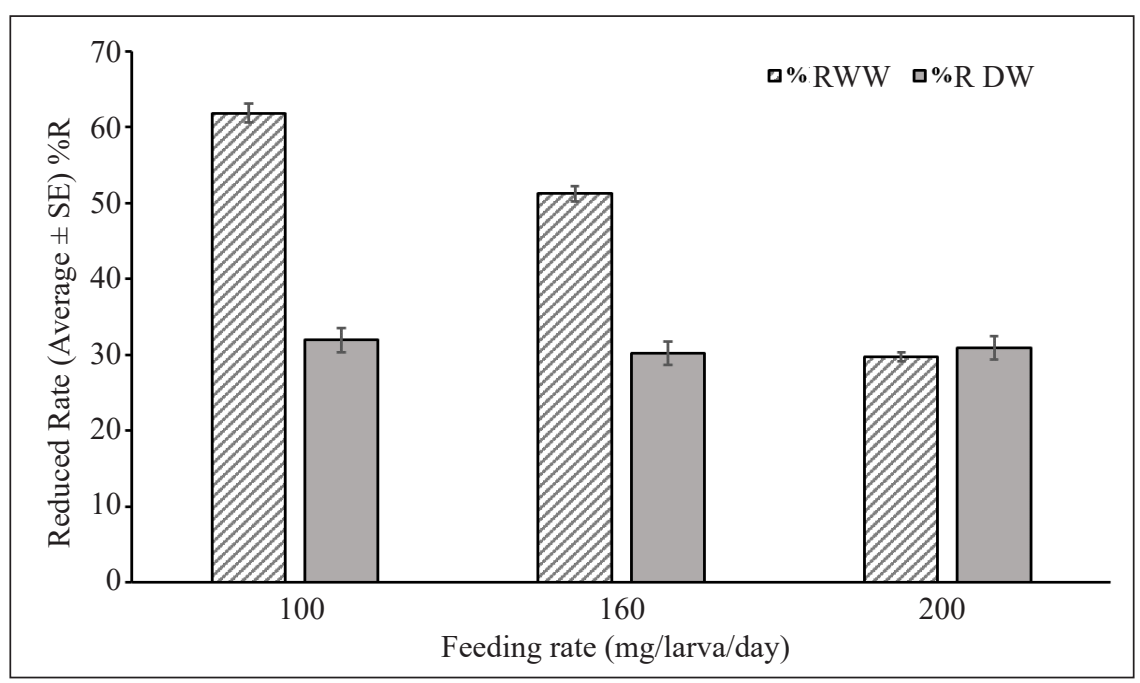

Figure 2. Reduction percentage (\%R) of Hermetia illucens larvae on three dietary supplies

for the dry weight analysis, the higher index metabolization $(7.89 \%)$ was reached when of reduction (0.66) was observed in the $\mathrm{T}_{4}$ fed $100 \mathrm{mg} /$ larva/day, however, ECI of treatment (200 mg/wet/day) (Figure 3). $\quad 6.18 \%$ with a diet of $200 \mathrm{mg} / \mathrm{larva} /$ day did

High WRI values indicate good not have significant differences $(p>0.0018)$. reduction efficiency (Diener et al., 2009) and From the values reported by Lardé (1990), these were reported, for dry basis analysis, the ECI was calculated for H. illucens larvae in the $\mathrm{T}_{4}$ treatment $(200 \mathrm{mg} / \mathrm{larva} /$ day $) . \quad$ fed in $\mathrm{CP}$, obtaining an ECI value $(6.03 \%)$

As for efficiency of conversion of very similar to the one found in this study ingested food (ECI), maximum feed (Table 2). 


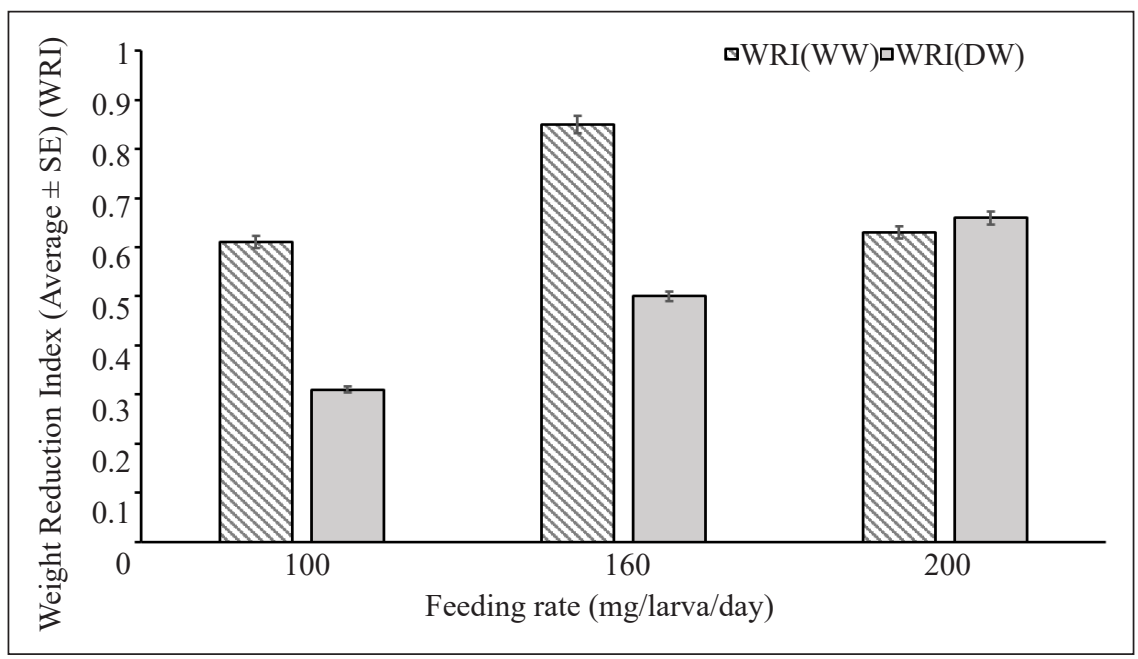

Figure 3. Weight Reduction Index (WRI) of Hermetia illucens larvae on three dietary supplies

Table 2

Larval and prepupal weight (mg) of Hermetia illucens fed different dietary supplies of CP (60, 100, 160, and $200 \mathrm{mg} /$ larva/day)

\begin{tabular}{ccccccccc}
\hline \multirow{2}{*}{$\begin{array}{c}\text { Developmental } \\
\text { stage }\end{array}$} & \multicolumn{2}{c}{$\mathrm{T}_{1}$} & \multicolumn{2}{c}{$\mathrm{T}_{2}$} & \multicolumn{2}{c}{$\mathrm{T}_{3}$} & \multicolumn{2}{c}{$\mathrm{T}_{4}$} \\
& $60 \mathrm{mg}$ & & $100 \mathrm{mg}$ & $160 \mathrm{mg}$ & $200 \mathrm{mg}$ \\
\cline { 2 - 9 } & Average & $\mathrm{N}$ & Average & $\mathrm{N}$ & Average & $\mathrm{N}$ & Average & $\mathrm{N}$ \\
\hline Larva* WW (mg) & $72.17 \pm 13.2 \mathrm{a}$ & 20 & $96.94 \pm 16.7 \mathrm{~b}$ & 20 & $95.80 \pm 19.1 \mathrm{~b}$ & 20 & $115.92 \pm 20.8 \mathrm{c}$ & 20 \\
Prepupa WW (mg) & $57.84 \pm 12.5 \mathrm{a}$ & 51 & $64.14 \pm 14.3 \mathrm{~b}$ & 320 & $65.99 \pm 10.8 \mathrm{~b}$ & 320 & $73.40 \pm 12.6 \mathrm{c}$ & 320 \\
\hline
\end{tabular}

Note. * The measurement of the day in which $50 \%$ of the prepupae had migrated, except for $\mathrm{T}_{1}$

From the formula (4), the ECI value for larvae fed with chicken, pig and cow manure was calculated with the data presented by Oonincx et al. (2015a), these were respectively $8.92,10.89$, and $8.08 \%$. Additionally, from the data provided by Banks et al. (2014) we calculated the ECI values for larvae fed with pig manure (Newton et al., 2005b) and with municipal solid waste (Sheppard et al., 1994) obtaining values of 10.4 and $17.3 \%$ respectively.

The high values of ECI (7.89\%) obtained in this study, reflect the capacity that larvae of $H$. illucens have to use in growth (weight gained) the ingested CP.

\section{Weight Gain and Development Time}

Larvae fed 100, 160, and $200 \mathrm{mg} /$ larva/day (wet weight $60 \%$ moisture, $40 \mathrm{mg} / \mathrm{larva} /$ day DW), took respectively $77.95,46.45$, and 38.65 days to complete the bioconversion process. In terms of weight gained during the process for dietary supplies of 60 , 100,160 , and $200 \mathrm{mg} /$ larva/day, the larval weight was 72.17, 96.9, 95.8, and 115.9 $\mathrm{mg}$ respectively and for pre-pupas it was $57.7,64.7,65.9$, and $73.4 \mathrm{mg}$, respectively (Table 2).

In terms of larval and prepupal weight, significant differences were found between 
treatments $T_{1}(60 \mathrm{mg} /$ larva/day $)$ and $\mathrm{T}_{4}$ (200 mg/larva/day), between treatments $\mathrm{T}_{2}$ (100 mg/larva/day) and $\mathrm{T}_{3}$ (200 mg/larva/ day) no significant differences were found $(p>0.8431, p>0.0636$ larva and prepupa respectively) (Figure 3).

Larvae fed with $200 \mathrm{mg} /$ larva/day of CP, presented the highest weight (average 115.9 $\mathrm{mg}$ ). These larvae required a shorter average time of development (38.65 days), the larvae fed with the lowest dietary supply $(60 \mathrm{mg} /$ larva/day), presented the lowest weight at the end of the process $(57.7 \mathrm{mg})$; as for the prepupae a dietary supply of $200 \mathrm{mg} / \mathrm{larva} /$ day presented the highest weight $(73.4 \mathrm{mg})$, where dietary supplies of $100 \mathrm{mg} /$ larva/day, resulted in a prepupal weight of $64.7 \mathrm{mg}$, corresponding to a larval duration of 77.95 days, the longest of the whole process (Table 2, Figure 4).
Observations in $\mathrm{T}_{1}(60 \mathrm{mg} / \mathrm{larva} /$ day $)$, were suspended at 103 days, when only $6.4 \%$ of prepupae had migrated. From a biological point of view, low dietary supplies increase larval development time and accumulated weight (Figure 4), the fact that larval development time is prolonged, with poor dietary supplies, representing a high adaptability in bioconversion operations with variable food supplies (Diener et al., 2009).

The maximum percentage of survival $(89.9 \%)$ was reached in those larvae fed with $200 \mathrm{mg} /$ larva/day of CP, less than $24 \%$ of the larvae could not reach the prepupa stage. No significant differences were found between the percentage of survival and the different treatments, however, a direct linear relation is appreciated, between the percentage of survival and the dietary availability (Table 1).

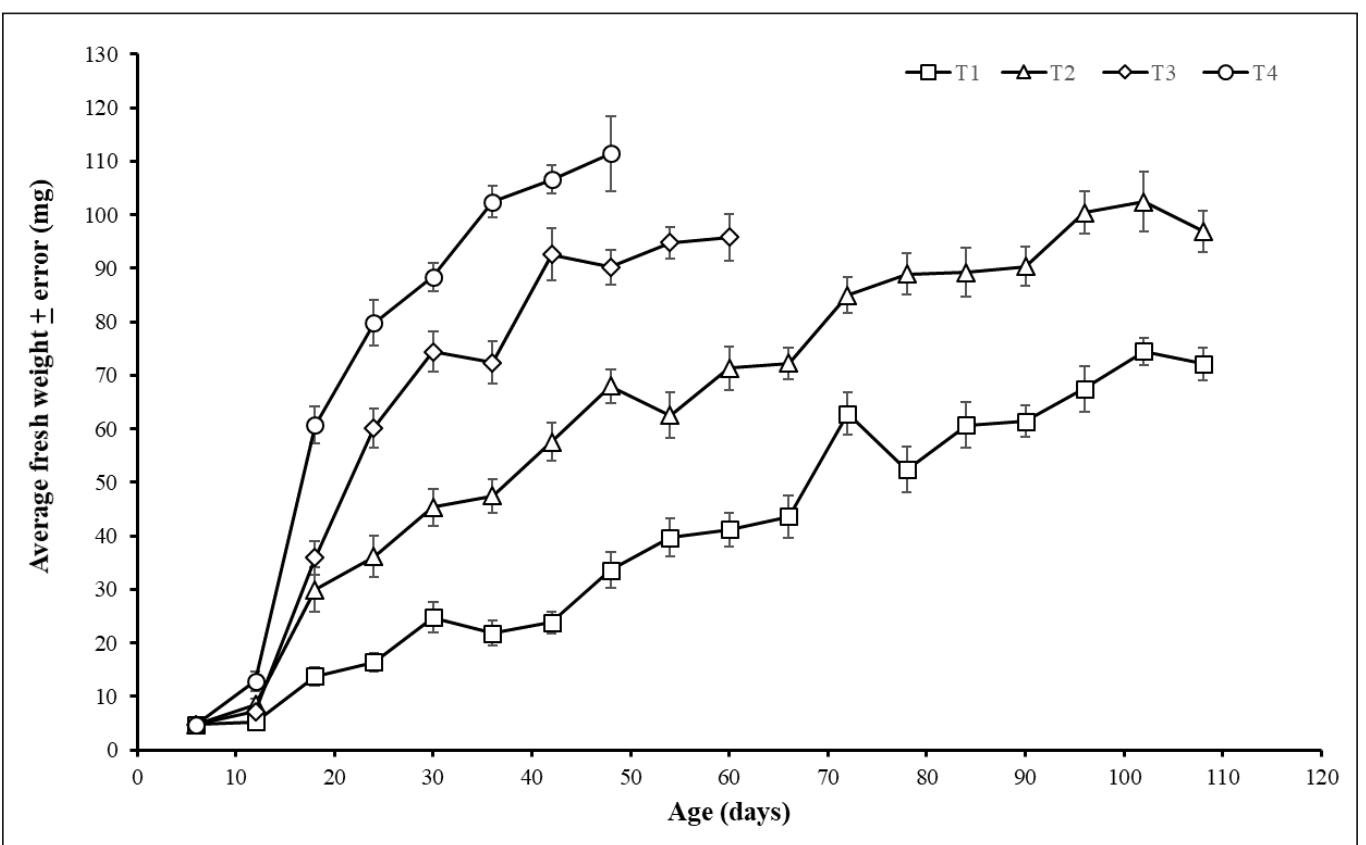

Figure 4. Increase in weight on a wet basis (Average \pm Error) of Hermetia illucens larvae with respect to development time, in four different treatments $\mathrm{T} 1=60, \mathrm{~T} 2=100, \mathrm{~T} 3=160$, and $\mathrm{T} 4=200 \mathrm{mg} / \mathrm{larva} /$ day 
The Relative Growth Rate (RGR) to the shorter time of larval development presented the best values with a diet of 200 (Figure 5).

$\mathrm{mg} /$ larva/day of $\mathrm{CP}$, this value is related

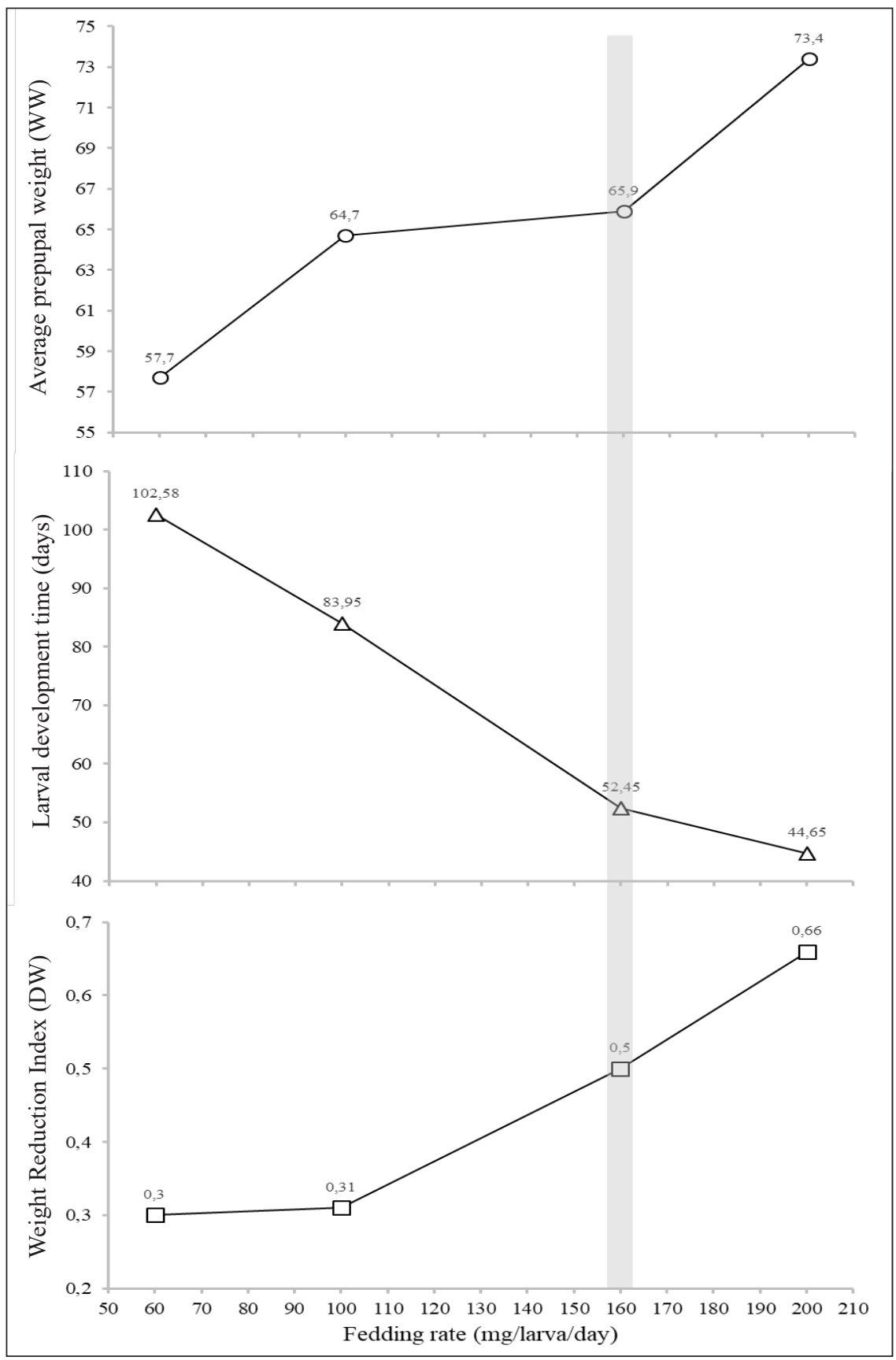

Figure 5. Prepupa weight (mg), larval development time (days), and reduction index (WRI), related to dietary supplies $(60,100,160$, and $200 \mathrm{mg} /$ larva/day). Shaded area indicated the optimal feeding rate 


\section{Effect of Caffeine on the Development of} Hermetia illucens

Both the $\mathrm{pH}$ (Mann Whitney, df $=40, \mathrm{~F}$ $=319, p=0.0142$ ) and temperature (Mann Whitney, $\mathrm{df}=40, \mathrm{~F}=176, p=0.272$ ) values were not found to affect the larval development of $H$. illucens (Figure 6A, $6 \mathrm{~B})$. The temperature of development varied between 26.49 and $36.63^{\circ} \mathrm{C}$.
Initially, the Solid Vegetable Waste (SVW) presented more acidic values (3.33), than the $\mathrm{CP}$ (6.76). This was due to the fact that the SVW was composed, among others, by pineapple residues, which has a $\mathrm{pH}$ of 3.6 (Ulloa, 2007). However, soon after (less than three days), the $\mathrm{pH}$ of both the $\mathrm{CP}$ and the SVW became basic. In addition, both CP and SVW were observed to decrease

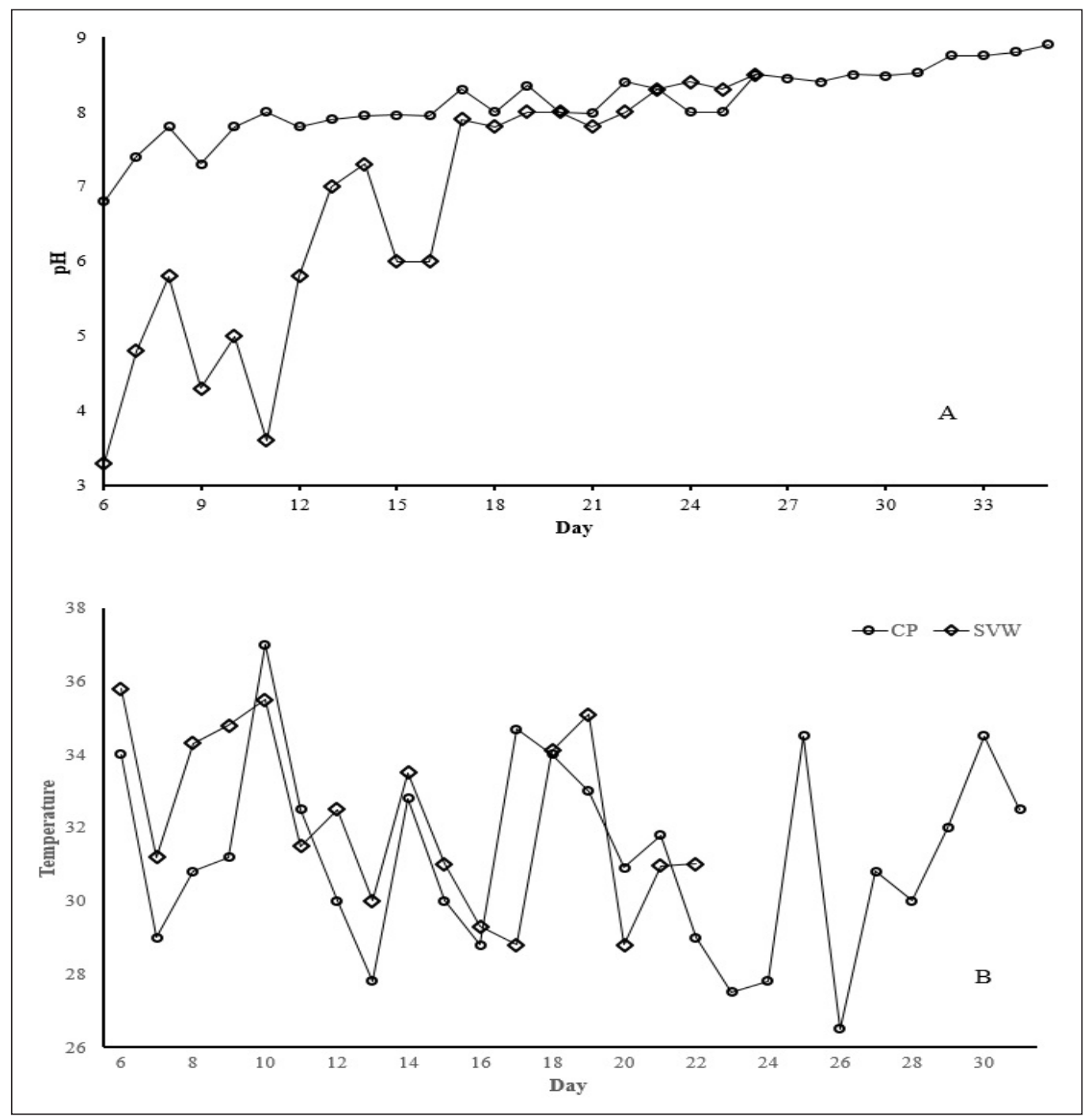

Figure 6. Variations in $\mathrm{pH}(\mathrm{A})$ and temperature (B), between treatments during the larval development of Hermetia illucens 
in $\mathrm{pH}$ each time new food was supplied (Figure 6A).

Under average environmental conditions of $31.74 \pm 2^{\circ} \mathrm{C}$, RH of $51.85 \pm 5 \%$, and $\mathrm{CP}$ with $0.5 \%$ caffeine, it was found that the duration of larval development was longer in $\mathrm{CP}$ than in SVW $(\mathrm{F}=7023.73, p=0.000)$ (Table 3).
Although no significant differences were found in pupal duration in $\mathrm{CP}$ and SVW $(F=3.39, p=0.066)$, the percentage of survival was higher in SVW (83.7\%) than in CP (71.17\%) (Table 3 ) and the migration of prepupae was first in SVW (19 days) than in CP (26 days) (Figure 7).

\section{Table 3}

Survival rate and duration in days, in the different stages of development of Hermetia illucens, fed with two different diets

\begin{tabular}{|c|c|c|c|c|c|c|c|c|}
\hline \multirow{4}{*}{ Diet } & \multirow{2}{*}{\multicolumn{2}{|c|}{$\begin{array}{c}\text { Egg } \\
(\mathrm{n}=6570)\end{array}$}} & \multicolumn{4}{|c|}{ Development } & \multirow{2}{*}{\multicolumn{2}{|c|}{ Adult development }} \\
\hline & & & \multicolumn{2}{|c|}{ larva to prepupa } & \multicolumn{2}{|c|}{ prepupa to adult } & & \\
\hline & & & & & & & Male & Female \\
\hline & $\begin{array}{c}S \\
(\%)\end{array}$ & $\begin{array}{c}\mathrm{D} \\
\text { (days) }\end{array}$ & $\begin{array}{c}S \\
(\%)\end{array}$ & $\begin{array}{c}\mathrm{D} \\
\text { (days) }\end{array}$ & $\begin{array}{c}\mathrm{S} \\
(\%)\end{array}$ & $\begin{array}{c}D \\
\text { (days) }\end{array}$ & $\begin{array}{c}\mathrm{D} \\
\text { (days) }\end{array}$ & $\begin{array}{c}\mathrm{D} \\
\text { (days) }\end{array}$ \\
\hline $\begin{array}{c}C P \\
(n=2000)\end{array}$ & 88.73 & $3.57 \pm 0.53$ & 74,8 & $34.8 \pm 4.4 \mathrm{a}$ & 71.17 & $18.99 \pm 1.74 \mathrm{a}$ & $3.9 \pm 2.9 \mathrm{a}$ & $3.7 \pm 2.44 \mathrm{a}$ \\
\hline $\begin{array}{c}\text { SVW } \\
(\mathrm{n}=2000)\end{array}$ & - & - & 78.4 & $24.3 \pm 2.1 b$ & 83.7 & $19.3 \pm 1.56 \mathrm{a}$ & $3.6 \pm 2.72 \mathrm{a}$ & $3.5 \pm 3.23 \mathrm{a}$ \\
\hline
\end{tabular}

Note. $\mathrm{SVW}=$ solid vegetal waste, $\mathrm{CP}=$ coffee pulp, $\mathrm{S}=$ survival, $\mathrm{D}=$ duration

Average values followed by an identical letter means that they do not vary significantly $(p<0.05)$

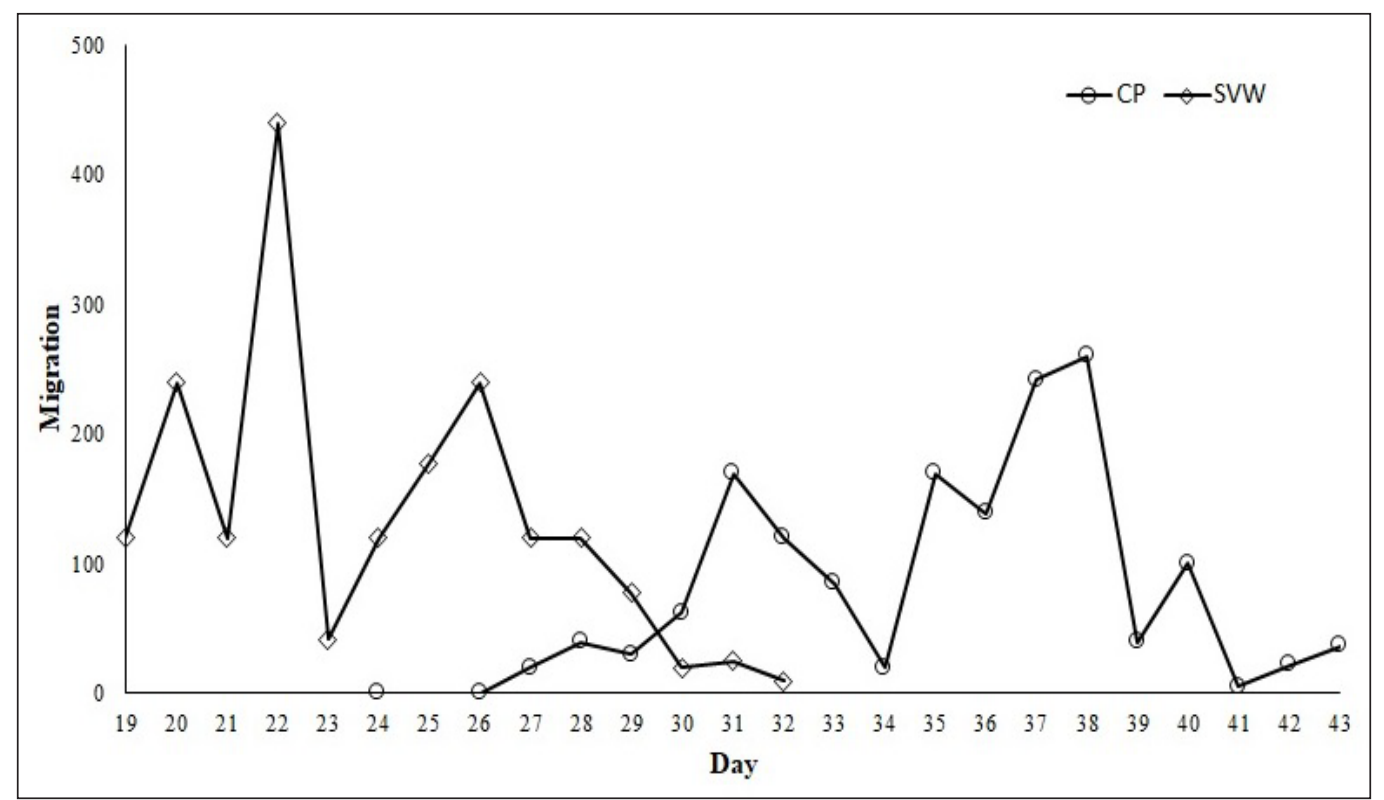

Figure 7. Start and end of prepupal migration of Hermetia illucens, fed with CP and SVW 


\section{DISCUSSION}

The values of the average percentage reduction in dry base (30.22 and 32\%) were similar to those obtained by Oonincx et al. (2015a) in chicken, pig and cow excrement (36.7, 37.7, and $36.8 \%$, respectively), while Lardé (1990) reported a reduction of 29 in CP. $8 \%$. The same author, mentioned in the analysis of his results that Booram et al. (1977) obtained a percentage reduction between 20.3 and $21.7 \%$ in pig excrement, percentages lower than those obtained in this study.

The trend in the linear relationship found between the average percentage of reduction and feeding rate, coincides with that expressed by Myers et al. (2008), who by feeding $H$. illucens larvae with 90 and $233 \mathrm{mg} /$ larva/day of cow manure, found a reduction of 58 and $33 \%$ respectively. Similar results were obtained by Manurung et al. (2016), when feeding larvae with 12.5 and $200 \mathrm{mg} /$ larva/day of rice "husk", the percentage of reduction being 31.5 and $9.58 \%$ respectively, maintaining an inverse linear relationship.

Authors such as Myers et al. (2008) and Manurung et al. (2016), agreed that an inverse relationship between the amount of food and the percentage of reduction was explained by the fact that, with less food available, the larvae consumed the totality of it, which of course compromised the development duration and the biology of the adult (Tomberlin et al., 2002).

The WRI values found, are similar to those obtained by Manurung et al. (2016), which are $0.58-0.24$ for dietary supplies of 12.5-200 mg/larva/day respectively. However, the WRI/diet ratio in unit of " $\mathrm{mg}$ " maintains for Manurung et al. (2016), an inverse relationship, these results may find justification in the loss of moisture.

The high ECI values (7.89\%) obtained in this study reflect the capacity that $H$. illucens larvae have to use the ingested CP for growth (weight gained). These values are low compared with the data obtained from Oonincx et al. (2015a) and Banks et al. (2014), indicating the low digestibility of CP, which the larvae have, does not significantly affect either their bioconversion efficiency or their biology.

In terms of weight gain and developmental time, the results obtained in this study were similar to those presented by authors such as Supriyatna et al. (2016) when $H$. illucens larvae were fed cassava, chicken were fed supplement (Diener et al. 2009), and Furman et al. (1959) found that under poor dietary conditions, the larval period was extended by more than four months.

Diener et al. (2009) stated, supported by Nijhout and Williams (1974) that under poor nutritional conditions, larvae would feed until they reached the minimum energy reserves required to reach the pupal stage.

The relationship between the duration of larval development and dietary supply is consistent with those reported by Diener et al. (2009) when feeding larvae with chicken feed, with the larval development of 10.6 days, while larval development was 41.1 days when the larvae were fed with rice husks (Manurung et al. 2016). The 
differences found can be justified in the nutritional components of the different diets, that is, the shortest duration (10.6 days) was found in larvae fed with chicken feed. This type of feed has a balanced component, with a protein content (20\%) higher than that found in CP (approximately 11\%). On the other hand, the low digestibility of structural carbohydrates such as lignin, cellulose, and hemicellulose present in diets based on rice husks and $\mathrm{CP}$, have an effect, increasing the larval development time. Nguyen et al. (2013), stated that proteins were the most important dietary component in the larval development of $H$. illucens, so that the higher the proteins content, the shorter the time of larval development. The diet used in this study, unlike all those mentioned, contained $0.5 \%$ caffeine. According to the data obtained, caffeine should be considered as a dietary element that can affect (although not significantly) the time of larval development.

Regarding the linear relationship found between the percentage of survival and dietary availability, the results observed are related to those reported by Manurung et al. (2016), who with dietary supplies (rice husk) of 12.5, 25, 50, 100, and 200 $\mathrm{mg} /$ larva/day, presented survival rates of 51.21, 74.24, 80.90, 91.79, and 98.27\% respectively, despite finding significant differences, the direct linear relationship is maintained. Similar results were obtained by Myers and collaborators (2008), who when feeding larvae with $133.3 \mathrm{mg} /$ larva/ day of cow manure, reported a survival rate of $84.50 \%$.
The relationship found between the shortest development time and the best RGR values is justified by Manurung et al. (2016), who stated that RGR values would depend on factors such as feed availability, that is, higher RGR values occurred in those cases where feed availability was the highest. Under optimal nutritional conditions, larvae adjust their energy consumption, and prioritize energy utilization for body growth and metabolism. Under poor dietary conditions, larvae slow down their growth and prioritize their energy on sustaining their survival and once the nutritional conditions change, the strategy may shift towards increasing size, this characteristic behavior of holometabolic insects, denominated by Manurung et al. (2016) as phenotypic plasticity.

In Figure 8, the results obtained in this study are compared with those reported by Manurung et al. (2016), who fed rice hull to H. illucens larvae.

Development occurred well at temperatures between 26.49 and $36.63^{\circ} \mathrm{C}$, ranges that coincide with the results reported by Alattar (2012), in studies with H. illucens larvae, fed with leachate of plant origin.

Concerning the $\mathrm{pH}$, our results are consistent with those obtained by Alattar (2012), who stated that H. illucens larvae modified the $\mathrm{pH}$ of the medium, developing in ranges between 0.7 and 13.7. These results match those presented by Meneguz et al. (2018), where they stated that larval activity modified the $\mathrm{pH}$ from the fourth day, and that they tolerated wide ranges of $\mathrm{pH}(4.0-9.5)$. 


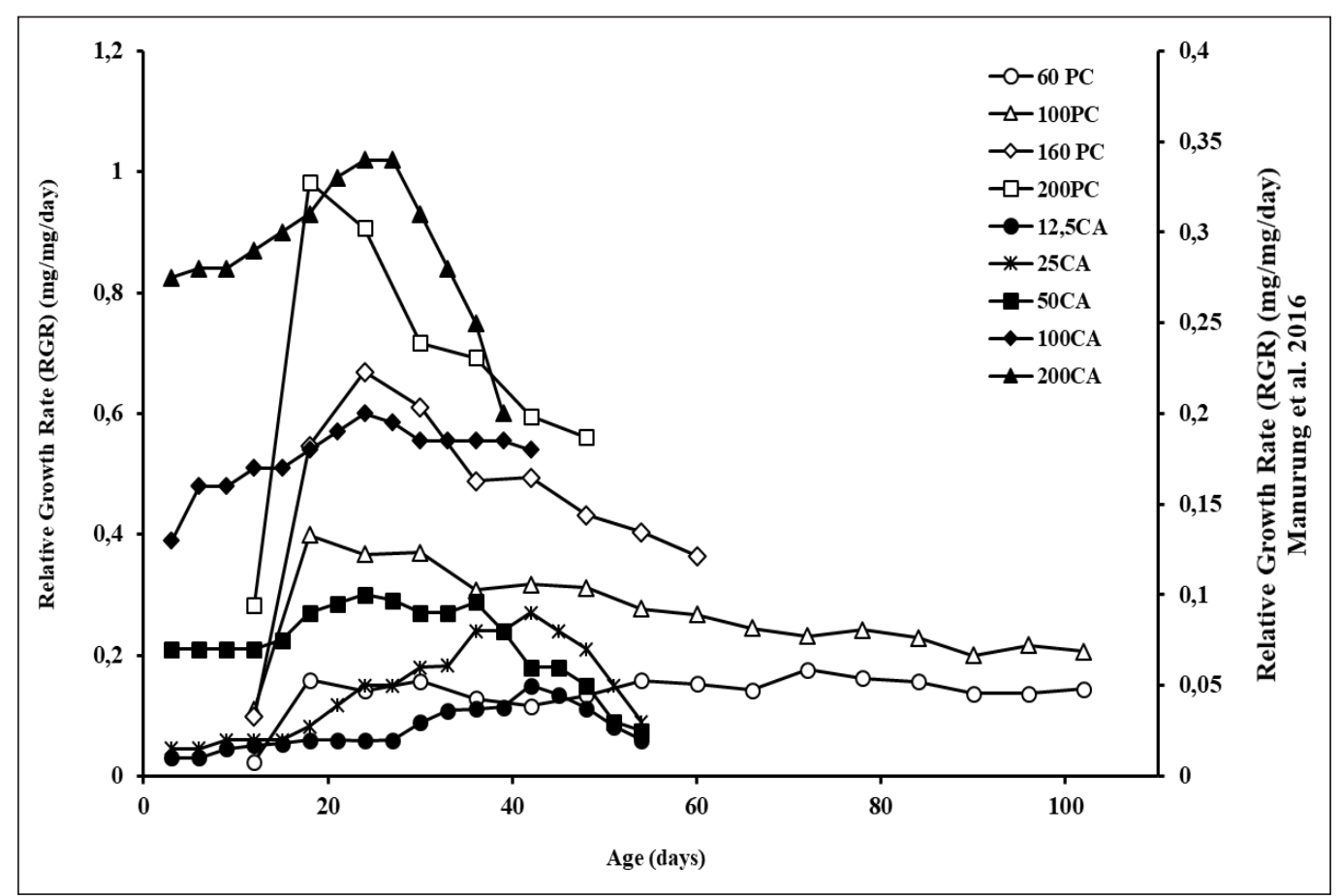

Figure 8. Comparative Relative Growth Rate (RGR) Hermetia illucens larvae fed with CP

\section{CONCLUSIONS}

Hermetia illucens has the capacity to efficiently digest CP. The survival rate of immature stages, the bioconversion time, the percentage and reduction index, are positive in regard to its bioconversion efficiency. Dietary supplies of 160-200 mg/larva/day allow for efficient bioconversion of CP. Caffeine present in fresh $\mathrm{CP}$ does not affect the development speed of immature $H$. illucens. The use of the "black soldier fly" in the degradation of the CP in coffee farms, is envisioned as a valid alternative to mitigate the enormous environmental impact caused by the spill of these to the ecosystem, and additionally offers a good opportunity in the harnessing of the generated by-products.

\section{ACKNOWLEDGEMENTS}

The authors would like to thank the Administrative Department of Science, Technology and Innovation (COLCIENCIA), for funding the project Valorisation of agrifood residuals with insect technologies (EntoWaste) in the framework of the Second Transnational Call EraNet-LAC of (ELAC2015-T03-0580); special thanks to José Noé Castro, José Guerrero, Fernando Capote, and Raúl Canal for facilitating the coffee pulp used during this research; to the Universidad del Valle (Grupo de Investigaciones Entomológicas, Professors Gloria Delfina Lasso de Fernández of the Chemical Engineering Department, and Enrique Peña and Wilmar Bolivar of the Biology Department) for facilitating the different equipment used. 


\section{REFERENCES}

Alattar, M. A. (2012). Biological treatment of leachates of microaerobic fermentation [Master's thesis, Portland State University]. Pdxscholar. https://pdxscholar.library.-pdx.edu/ open_access_etds/905/

Arango, G., Vergara, R., \& Mejía, H. (2004). Análisis composicional, microbiológico y digestibilidad de la proteína de la harina de larvas de Hermetia illucens L. (Diptera: Stratiomyidae) en Angelópolis-Antioquia, Colombia [Compositional, microbiological and digestibility analysis of the protein of the larvae meal of Hermetia illucens L. (Diptera: Stratiomyidae) in Angelopolis-Antioquia, Colombia]. Revista Facultad Nacional de Agronomía, 57(2), 2491-2499.

Banks, I., Gibson, W., \& Cameron, M. (2014). Growth rates of black soldier fly larvae fed on fresh human faeces and their implication for improving sanitation. Tropical Medicine International Health, 19(1), 14-22. https://doi.org/10.1111/ tmi. 12228

Blandón, C., Rodríguez, V., \& Dávila, M. (1999). Caracterización microbiológica y físico-química de los subproductos del beneficio del café en proceso de compostaje [Microbiological and physical-chemical characterization of coffee processing by-products in the composting process]. Cenicafé, 49, 169-185.

Bondari, K., \& Sheppard, C. (1987). Soldier fly, Hermetia illucens L., larvae as feed for channel catfish, Ictalurus punctatus (Rafinesque), and blue tilapia, Oreochromis aureus (Steindachner). Aquaculture Research, 18(3), 209-220. https:// doi.org/10.1111/j.1365-2109.1987.tb00141.x

Booram, C. V. Jr., Newton, G. L., Hale, O. M., \& Barker, R. W. (1977). Manure residue as a substrate for protein production via Hermetia illucens larvae. https://agris.fao.org/agris-search/ search.do?recordID=US19780337139
Canary, G. (2009). Diseño y gestión de un proceso para reciclar desechos orgánicos con la larva Hermetia illucens para producir harina de larva [Design and management of a process to recycle organic waste with the larva Hermetia illucens to produce larva flour]. https://www. semanti-cscholar.org/paper/Dise \%C3\%B1o-ygesti $\% \mathrm{C} 3 \% \mathrm{~B} 3 n$-de-un-proceso-para-reciclarcon-la-Canary-Gonzalez/2750a9d99f3b265bd0 67ac186279aca1-79a7f403

Diener, S., Studt, N. M., Roa, F., Zurbügg, C., \& Tockner, K. (2011). Biological treatment of municipal organic waste using black soldier fly larvae. Waste Biomass Valorization, 2(4), 357363. https://doi.org/10.1007/s12649-011-9079-1

Diener, S., Zurbrügg, C., \& Tockner, K. (2009). Conversion of organic material by black soldier fly larvae: Establishing optimal feeding rates. Waste Management and Research, 27(6), 603610. https://doi.org/10.1177/0734242X09103838

Elías, L. (1978). Composición química de la pulpa de café y otros subproductos [Chemical composition of coffee pulp and other byproducts]. In J. E. Braham (Ed.), Pulpa de café: Composición, tecnología y utilización [Coffee pulp: Composition, technology and use] (pp. 19-29). Institute of Nutrition of Central America and Panama.

Furman, D., Young, R., \& Catts, P. (1959). Hermetia illucens as a factor in the natural control of Musca domestica Linnaeus. Journal of Economic Entomology, 52(5), 917-921. https:// doi: 10.1177/0734242X09103838

Gamboa, E., \& Jasbón, N. (2008). Degradación de residuos de almidón y cárnicos, mediante la producción de la larva soldado negra (Hermetia illucens L.) [Degradation of starch and meat residues by production of the black soldier larva (Hermetia illucens L.)]. https://ciencia.lasalle. edu.co/-ing_ambiental_sanitaria/669 
Hale, O. M. (1973). Dried Hermetia illucens larvae (Diptera: Stratiomyidae) as a feed additive for poultry. Journal of the Georgia Entomological Society, 8, 16-20.

Jaramillo, G., \& Zapata, L. (2008). Aprovechamiento de los residuos sólidos orgánicos en Colombia [Use of organic solid waste in Colombia]. http://www.enjambre.gov.co/enjambre/file/ download/125298

Kim, W., Bae, S., Park, K., Lee, S., Choi, Y., Han, S., \& Koh, Y. (2011). Biochemical characterization of digestive enzymes in the black soldier fly, Hermetia illucens (Diptera: Stratiomyidae). Journal of Asia-Pacific Entomology, 14(1), 1114. https://doi.org/10.1016/j.aspen.2010.11.003

Lardé, G. (1990). Recycling of coffee pulp by Hermetia illucens (Diptera: Stratiomyidae) larvae. Biological Wastes, 33(4), 307-310. https://oi: 10.1016/0269-7483(90)90134-E

Lord, W. D., Goff, M. L., \& Adkins, T. R. (1994). The black soldier fly Hermetia illucens (Diptera: Stratiomyidae) as a potential measure of human post-mortem interval: Observations and case histories. Journal of Forensic Sciences, 39(1), 215-22. https://doi: 10.1111/j.15564029.2008.00659.x

Manurung, R., Supriatna, A., Esyanthi, R., \& Putra, R. E. (2016). Bioconversion of rice straw waste by black soldier fly larvae (Hermetia illucens L.): Optimal feed rate for biomass production. Journal of Entomology and Zoology Studies, 4(4), 1036-1041. https://www.entomoljournal.com/ archives/2016/vol4issue4/PartK/4-3-163-796

Meneguz, M., Gasco, L., \& Tomberlin, J. K. (2018). Impact of $\mathrm{pH}$ and feeding system on black soldier fly (Hermetia illucens, L; Diptera: Stratiomyidae) larval development. PLoS One, 13(8), e0202591. https://doi.org/10.1371/journal. pone. 0202591
Molina, M., Lechuga, R., \& Bressan, R. (1990). Valor nutritivo de la pulpa de café sometida a fermentación sólida usando Aspergillus niger en pollos y cerdos [Nutritional value of coffee pulp subjected to solid fermentation using Aspergillus niger in chickens and pigs]. Agronomía Mesoamericana, 1, 79-82. https:// doi.org/10.15517/am.v1i0.25350

Myers, H., Tomberlin, J., Lambert, B., \& Kattes, D. (2008). Development of black soldier fly (Diptera: Stratiomyidae) larvae fed dairy manure. Environmental Entomology, 37(1), 11-15. https:// doi.org/10.1093/ee/37.1.11

Newton, G. L., Sheppard, D. C., Watson, D. W., Burtle, G. J., Dove, C. R., Tomberlin, J. K., \& Thelen, E. (2005a). The black soldier fly, Hermetia illucens, as a manure management/resource recovery tool. https://www.researchgate.net/ publication/237345975_The_black_soldier_ fly_Hermetia_illucens_as_a_manure managementresource_recovery_tool

Newton, G. L., Sheppard, D. C., Watson, D. W., Burtle, G., \& Dove, R. (2005b). Using the black soldier fly, Hermetia illucens, as a value-added tool for the management of swine manure. https:// www.researchgate.net/publication/267377822_ Using_the_Black_Soldier_Fly_Hermetia_ Illucens_as_a_Value-Added_Tool_for_the_ Management_of_Swine_Manure

Nguyen, T., Tomberlin, J., \& Vanlaerhoven, S. (2013). Influence of resources on Hermetia illucens (Diptera: Stratiomyidae) larval development. Journal of Medical Entomology, 50(4), 898-906. https://doi.org/10.1603/ME12260

Nijhout, H. F., \& Williams, C. M. (1974). Control of molting and metamorphosis in tobacco hornworm, Manduca sexta (L): Growth of lastinstar larva and decision to pupate. Journal of Experimental Biology, 61(2), 481-491. 
Noriega, A., Silva, R., \& García de Salcedo, M. (2008). Revisión: Utilización de la pulpa de café en alimentación animal [Review: Use of coffee pulp in animal feed]. Zootecnia Tropical, 26(4), 411-419.

Oonincx, D., Van Huis, A., \& Van Loon, J. (2015a). Nutrient utilization by black soldier flies fed with chicken, pig, or cow manure. Journal of Insects as Food and Feed, 1(2), 131-139. https://doi. org/10.3920/JIFF2014.0023

Pandey, A. K., Mishra, B. K., Arora, A., Singh, S., \& Lata-Ray, R. C. (2011). Bioaugmentation and biovalourization of agro-food and beverage industry effluents. In A. Singh, N. Parmar, \& R. Kuhad (Eds.) Bioaugmentation, biostimulation and biocontrol (pp. 85-106). Springer. https:// doi.org/10.1007/978-3-642-19769-7_5

Parra, S., Carrejo, N., \& Gómez, C. (2015). Effects of larval density and feeding rates on the bioconversion of vegetable waste using black soldier fly larvae Hermetia illucens (L.), (Diptera: Stratiomyidae). Waste Biomass Valorization, 6(6), 1059-1065. https://doi.org/10.1016/j. jclepro.2018.10.017

Pujol-Luz, J. R., Francez, P. A. C., Ururahy-Rodrigues, U., \& Constantino, R. (2008). The black soldier by, Hermetia illucens (Diptera, Stratiomyidae), used to estimate the postmortem interval in a case in Amapá State, Brazil. Journal of Forensic Sciences, 53(2), 476-478. https://doi. org/10.1111/j.1556-4029.2008.00659.x

Rodríguez. V., \& Zambran, D. (2010). Los subproductos del café: Fuente de energía renovable [Coffee by-products: A source of renewable energy]. Cenicafé Press.

Rubio, J. (1973). Composición química y digestibilidad in vitro de la pulpa de café [Chemical composition and in vitro digestibility of coffee pulp] [Master's thesis, Universidad Nacional]. Universidad Nacional Research Repository. http://hdl.handle.net/20.500.12324/23189
Scriber, J., \& Slansky, F. (1981). The nutricional ecology of immature insects. Annual Review of Entomology, 26(1), 183-211. https://doi. org/10.1146/annurev.en.26.010181.001151

Sheppard, D. C., Newton, G. L., Thompson, S. A., \& Savage, S. (1994). A value-added manure management-system using the black soldier fly. Bioresource Technology, 50(3), 275-279. https:// doi.org/10.1016/0960-8524(94)90102-3

Sheppard, D. C., Tomberlin, J. K., Joyce, J. A., Kiser, B. C., \& Sumner, S. M. (2002). Rearing methods for the black soldier fly (Diptera: Stratiomyidae). Journal of Medical Entomology, 39(4), 695-698. https://doi.org/10.1603/0022-2585-39.4.695

Supriyatna, A., Manurung, R., Rachmi-Esyanti, R., \& Putra, R. E. (2016). Growth of black soldier larvae fed on cassava peel wastes, an agriculture waste. Journal of Entomology and Zoology Studies, 4(6), 161-165.

Tomberlin, J., Shepard, D., \& Joyce, J. (2002). Selected life-history traits of black soldier flies (Diptera: Stratiomyidae) reared on three artificial diets. Annals of the Entomological Society of America, 95(3), 379-386. https:// doi.org/10.1603/00138746(2002)095[0379:SLHTOB]2.0.CO;2

Ulloa, J. A. (2007). Frutas auto estabilizadas en el envase por la tecnología de obstáculos [Fruits self-stabilized in the package by the obstacle technology]. Universidad Autónoma de Nayarit Press.

Waldbauer, G. P. (1968). The consumption and utilization of food by insects. In Advances in Insect Physiology, 5, 229-288. https://doi. org/10.1016/S0065-2806(08)60230-1

Warburton, K., \& Hallman, V. (2002). Processing of organic materials by the soldier fly, Hermetia illucens. https://www.agrifutures.com.au/wpcontent/uploads/publications/01-174.pdf 
Zheng, L., Cai, H., Garza, E., Yu, Z., \& Zhou, S. (2011). From organic waste to biodiesel: Black soldier fly, Hermetia illucens, makes if feasible. Fuel, 90(4), 1545-1548. https://doi. org/10.1016/j.fuel.2010.11.016
Zheng, L., Zhang, J., \& Yu, Z. (2012). Double the biodiesel yield: Rearing black soldier fly larvae, Hermetia illucens, on solid residual fraction of restaurant waste after grease extraction for biodiesel production. Renewable Energy, 41, 7579. https://doi.org/10.1016/j.renene.2011.10.004 